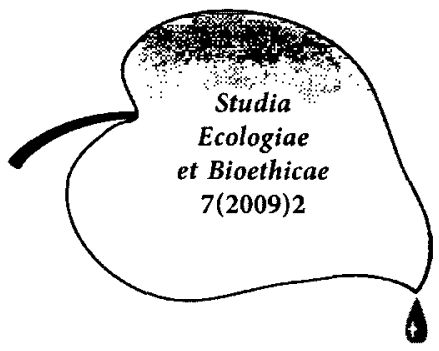

\title{
Thomas Berry - prorok ery ekozoicznej
}

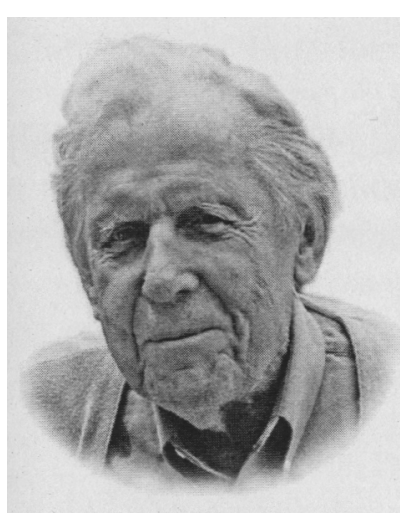

1 czerwca 2009 r. w wieku 94 lat zmarł Thomas Berry - katolicki duchowny, zakonnik, a jednocześnie wybitny uczony, który zainspirował wielu do pracy na rzecz ochrony środowiska naturalnego ${ }^{1}$. Thomas Berry był historykiem kultury, filozofem, teologiem oraz wybitnym znawcą religii i filozofii Azji. Sam najchętniej określał się jednak jako kosmolog i "geolog" - badacz Ziemi. Jako jeden z pierwszych wskazał na duchowy wymiar kryzysu ekologicznego. Tygodnik „Newsweek” w roku 1989 określił go „najbardziej prowokującym spośród nowego grona eko-teologów”2 . Berry należy do najbardziej dociekliwych badaczy relacji człowieka względem przyrody $\mathrm{i}$ ich implikacji dla religii ${ }^{3}$.

\section{Życie i twórczość}

William Nathan Berry urodził się 9 listopada 1914 r. w niewielkim, malowniczo położonym miasteczku Greensboro w Karolinie Północnej. Był trzecim spośród trzynaściorga dzieci. Jak sam wielokrotnie to stwierdzał, jego szacunek i troska o przyrodę miały swój początek w estetycznym przeżyciu piękna przyrody na przedmieściach rodzinnego miasta ${ }^{4}$. $Z$ perspektywy lat opisał to następująco: „...to doświadczenie wniosło w moje życie coś, co wydaje się wyjaśniać

1 Fotografia Thomasa Berry'ego została wykonana przez Caroline Webb w Greensboro latem $2003 \mathrm{r}$. i zamieszczona na witrynie poświęconej temu uczonemu: <www.EarthCommunity.org>, (data dostępu: 10.10.2009).

2 Por. R. Heffern, Thomas Berry, "National Catholic Reporter" z 10 sierpnia 2001, tekst dostępny w internecie <http://www.natcath.com/NCR_Online/archives/081001/081001a.htm>, (data dostępu: 29.09.2009).

3 Por. tamże.

4 Por. A. C. Revkin, Thomas Berry, Writer and Lecturer with a Mission for Mankind, Dies at 94, "The New York Times" z 3 czerwca 2009, tekst dostępny w internecie: <http://www.nytimes. com/2009/06/04/us/04berry.html>, (data dostępu: 29.09.2009). 
moje poglądy na głębszym poziomie, niż jakiekolwiek inne doświadczenia, które pamiętam"s. W roku 1934 wstąpił do nowicjatu Zgromadzenia Męki Pańskiej (pasjonistów) i rozpoczął studia filozoficzno-teologiczne zakończone święceniami kapłańskimi w 1942 r. zafascynowany myślą św. Tomasza z Akwinu przyjął jako imię zakonne „Thomas”, którego używał do końca swego życia. Po święceniach podjął studia z zakresu historii kultury na Catholic University of America, które ukończył w roku 1951 doktoratem na temat koncepcji historii w ujęciu Giambattisty Vico (1668-1744). Jeszcze w roku 1948 udał się do Pekinu w celu studiowania języka i kultury Chin, jednak - ze względu na przewrót polityczny Mao, już po roku musiał opuścić ten kraj. W latach 1951-1954 stacjonował w Niemczech, odbywając tam służbę wojskową jako kapelan. W latach 19561961 podjął wykłady $\mathrm{z}$ historii Indii i Chin na Seton Hall University w New Jersey, od 1961 do 1965 roku wykładał w Asian Institute na St. John's University, a począwszy od roku 1966 aż do roku 1979 pracował w Fordham University w Nowym Jorku, gdzie zapoczątkował i kierowal programem doktoranckim z zakresu historii religii. W roku 1970 założył Riverdale Center of Religious Research w Riverdale w stanie Nowy Jork i był jego dyrektorem do roku 1987. Jako profesor wizytujący wykładał także na Columbia University, Drew University oraz University of San Diego ${ }^{6}$.

O dynamizmie jego pomysłów intelektualnych i żywotności projektów świadczy najlepiej środowisko uczonych, artystów i działaczy ekologicznych, którzy powołali do życia fundację jego imienia oraz Center for Ecozoic Studies, których głównym celem jest promowanie „ekozoicznego społeczeństwa”. Dorobek naukowy Berry’ego stanowi kilka książek oraz kilkadziesiąt artykułów, którymi inspirował wielu pisarzy, filozofów, teologów i aktywistów środowiskowych, zarówno w Kościele katolickim, jak i poza nim. Do najważniejszych jego dzieł zalicza się:

- Buddhism, New York: Hawthorne Books 1966;

- The Religions of India, New York: Bruce-Macmillan 1971;

- The Dream of the Earth, San Francisco: Sierra Club Books 1988;

- Befriending the Earth, Mystic, CT: Twenty-third Publications 1991;

- The Universe Story (wraz z Brianem Swimme), San Francisco: Harper 1992;

- The Great Work: Our Way Into the Future, Crown Bell Publishers (Random House) 1999;

5 Por. R. Heffern, Thomas Berry, environmentalist-priest, dies, "National Catholic Reporter" z 1 czerwca 2009, tekst dostępny w internecie: <http://ncronline.org/news/ecology/thomasberry-environmentalist-priest-dies>, (data dostępu: 29.09.2009).

6 Por. tamże; por. także C. WEBB, Thomas Berry Short Biography, <www.earth-community.org/bio. htm>, (data dostępu: 29.09.2009). Mary Evelyn Tucker podaje nieco inne daty pracy T. Berry'ego w poszczególnych uczelniach. Por. M. E. TuCkER, An Intellectual Biography of Thomas Berry, [w:] T. BERry, M. E. Tucker (red.), Evening Thoughts. Reflecting on Earth as Sacred Community, San Franciso: Sierra Club Books 2006, s. 156-157. 
- Evening Thoughts: Reflecting on Earth as Sacred Community, Sierra Club Books. University of California Press $2006^{7}$.

Za wyjątkowy wkład w budowanie świadomości ekologicznej i nowatorskie koncepcje Thomas Berry był wielokrotnie nagradzany. Otrzymał osiem doktoratów honorowych ${ }^{8}$ oraz liczne nagrody i wyróżnienia, tak amerykańskie, jak i międzynarodowe. Pełny wykaz przyznanych mu wyróżnień zamieszcza Caroline Webb na witrynie internetowej www.earth-community.org/bio.htm. Na szczególną uwagę zasługuje powołanie w roku 1998 Fundacji im. Thomasa Berry'ego, której głównym celem jest wspieranie wizji tego niezwykłego uczonego oraz propagowanie jego naukowego dziedzictwa. Wraz z fundacją ustanowiono Nagrodę im. Thomasa Berry'ego, która ma promować uczonych zasłużonych na polu badań proekologicznych uwzględniających zaangażowanie religii i moralnego wymiaru zagrożeń ekologicznych. Do zarządu Thomas Berry Foundation należą m.in. uczniowie i przyjaciele uczonego: Mary Evelyn Tucker i John Grim - twórcy i założyciele Forum on Religion and Ecology ${ }^{9}$.

\section{Inspiracje intelektualne}

W myśli Berry'ego można dostrzec wpływy wielu uczonych, zarówno tych $\mathrm{z}$ dalekiej przeszłości, jak i żyjących współcześnie. Marjorie Hope i James Young wskazują na wyraźne związki jego koncepcji z pismami takich filozofów, jak Giambattista Vico, św. Tomasz, Teilhard de Chardin, Konfucjusz, Whitehead i Bergson. Berry chętnie nawiązuje też do Henry’ego Thoreau, Rachel Carson, Normana Myersa, Anne i Paula Erlichów oraz Ilii Prigogine, Jamesa Lovelocka i Briana Swimme ${ }^{10}$.

Wydaje się, że to właśnie badania nad twórczością Giambattisty Vico, a szczególnie jego koncepcji periodyzacji historii (wiek bogów, wiek herosów i wiek ludzi), zainspirowały Berry'ego do przedstawienia swojego pięciostopniowego podziału rozwoju kulturowego ludzkości: okres plemienno-szamański, okres

Pełny wykaz bibliografii Thomasa Berry'ego został zamieszczony na witrynie internetowej <www.earth-community.org/bio.htm>, (data dostępu: 10.10.2009).

8 Uniwersytety, które przyznały Berry'emu doktoraty honorowe: Elon University, Elon, North Carolina (2008); The Catholic Theological Union at Chicago, Illinois (2003); The College of Mt. St. Vincent, Riverdale, New York (1998); St. Mary's University. Halifax, Nova Scotia, Canada (1997); Loyola Marymount University, Los Angeles, California (1997); St.Thomas University of Miami, Florida (1994); Loyola University of New Orleans, Louisiana (1994); California Institute of Integral Studies, San Francisco, California (1993). Por. C. Webb, Thomas Berry Short Biography.

9 Por. Witryna internetowa poświęcona Thomasowi Berry'emu <www.thomasberry.org $>$, (data dostępu: 30.09.2009).

10 Por. M. Hope, J. Young, Thomas Berry and a New Creation Story, "The Christian Century" z 16-23 sierpnia 1989, s. 751. 
neolityczny, okres klasyczny, okres naukowo-technologiczny oraz okres ekologiczny. Tomistycznym echem w twórczości Berry’ego jest natomiast dążenie do przywrócenia harmonii i integralności porządku wszechświata zamierzonego przez Boga. W filozofii Teilharda dostrzegamy podstawy ujęcia przez Berry'ego koncepcji materii, jako tej, która nawet w swych najprostszych formach ma zarówno wymiar fizyczno-materialny, jak i psychiczno-duchowy oraz przeniesienie akcentu $\mathrm{w}$ myśli religii Zachodu $\mathrm{z}$ doktryny o odkupieniu na nauczanie o stworzeniu. Materia dla Berry'ego, podobnie jak dla Teilharda, nie jest martwa lub bezwładna lecz jest tajemniczą rzeczywistością posiadającą zarówno wymiar fizyczny, jak i duchowy. Świadomość jest więc obecna w całej rzeczywistości i łączy wszystkie formy życia ${ }^{11}$. Podobną myśl na temat obecności subiektywności w całej przyrodzie głosił też Hans Jonas ${ }^{12}$.

Konfucjanizm był natomiast dla Thomasa Berry’ego ważny ze względu na akcentowanie kosmologicznej dynamiki wszechświata, w której niebo, Ziemia $\mathrm{i}$ istoty ludzkie tworzą wzajemnie połączoną i zależną triadę. Berry, używając w stosunku do człowieka, zaczerpniętego z konfucjanizmu, terminu hsin (rozumiejące serce), wskazuje na ważną rolę człowieka we wszechświecie, która polega na wprowadzaniu harmonii między nim a przyrodą. Ponadto, optymistyczna wizja człowieka obecna w konfucjanizmie podkreśla dobro natury ludzkiej i jej zdolność do samodoskonalenia poprzez edukację, co z kolei prowadzi do zmian w społeczeństwie ${ }^{13}$.

\section{Najważniejsze koncepcje}

Znawca twórczości Thomasa Berry’ego - Rich Heffern - wymienia cztery kluczowe tezy jego twórczości ${ }^{14}$ :

1. Kiedy zniszczymy przyrodę, zniszczymy podstawę naszej religijnej wyobraźni.

Naszą zdolność do tworzenia wyobrażeń na temat Boga zawdzięczamy światu wokół nas. Mamy wspaniałą ideę Boga, ponieważ zawsze żyliśmy na planecie

11 Por. tamże; por. także M. E. Tucker, An Intellectual Biography of Thomas Berry, s. 153-154; $162-165$.

12 Por. H. JonAs, Zasada odpowiedzialności. Etyka dla cywilizacji technologicznej, Kraków: Platan 1996, s. 135.

13 Por. M. E. TUCKer, An Intellectual Biography of Thomas Berry, s. 159-160; por. także H. F. Greene, The Human Was Not Meant To Fail, wystapienie na konferencji "Ecological Civilization, Globalization and Human Development" Sanya, Chiny 21-23.06.2009 tekst dostępny na witrynie Center for Ecozoic Studies: <http://www.ecozoicstudies.org/ index.php?option $=$ com_content $\& v i e w=$ article\&id=162:the-human-was-not-meant-tofail\&catid=13:articles\&Itemid $=0>$, (data dostępu: 10.10.2009).

14 Por. R. HefFern, Thomas Berry 101. Some key ideas from the work of Fr. Thomas Berry, „National Catholic Reporter" z 1 czerwca 2009, tekst dostępny w internecie: <http://ncronline.org/news/ ecology/thomas-berry-101 >, (data dostępu: 24.09.2009). 
wypełnionej po brzegi wspaniałościami i tajemnicami, pięknem i cudownymi krajobrazami. Jak moglibyśmy sobie wyobrazić Boga jako zawsze świeży i twórczy świt, miłosiernego ojca, czułą matkę, czy cudownego doradcę, gdybyśmy nigdy nie doświadczyli tych cech w ludziach, krajobrazie i życiu wokół nas.

2. Zapomnieliśmy, że objawienie odnalezione w przyrodzie $i$ wszechświecie jest pierwotnym boskim objawieniem.

Objawienie jest przebudzeniem w nas poczucia boskiej tajemnicy i potęgi, jest sposobem, poprzez który Bóg komunikuje się z nami. Bóg objawia się w Biblii, ale także w opowiadaniach o początkach wszechświata, jego ewolucji oraz pojawieniu się człowieka. Thomas Berry podzielal myśl Tomasza z Akwinu, że błąd na temat stworzenia, oznacza błąd na temat Boga. W ciągu dwóch ostatnich wieków tak wiele dowiedzieliśmy się na temat wszechświata i rozwijającego się w nim życia, tzn. uzyskaliśmy nowe spostrzeżenia $\mathrm{z}$ tego pierwotnego objawienia. Teraz powinniśmy wziąć to pod uwagę w celu pełniejszego zrozumienia Boga i siebie samych. Wg Berry'ego, ważnym elementem wspomagającym to zrozumienie jest urok, który kształtuje ludzką duchowość. Podziw i piękno są podstawowymi duchowymi własnościami, lekarstwem na nasz duchowy autyzm. "Jeśli ta fascynacja, to pojawienie się życia nie byłoby przywołane, wówczas nasze dzieci nie miałyby sił niezbędnych do pokonywania cierpień odziedziczonych przez ludzką naturę. Mogłyby nigdy nie odkryć swego prawdziwego miejsca w bezkresie czasu i przestrzeni świata".

3. Nasze chrześcijańskie koncentrowanie się na osobowym zbawieniu powinno ustąić miejsca bardziej holistycznemu rozumieniu Jezusa Chrystusa.

Osobowa więź między człowiekiem i osobą Jezusa jest postrzegana jako podstawowa i zbawcza, a pomija się w niej wszystko inne. W takiej odkupieńczej wizji brakuje ważnego nauczania Chrystusa obecnego w pismach św. Pawła, np. „Wszystko w Nim ma istnienie” (Kol 1,17). Jest to sposób myślenia o Chrystusie jako osobie kosmicznej i o wszechświecie bardziej jako o wspólnocie podmiotów, niż zbiorze przedmiotów. „Cechy, które przypisujemy człowiekowi... są obecne w całym świecie. Nawet na poziomie pierwiastków zauważamy zdolność samoorganizowania się i zdolność bliskich relacji. Te wszechobecne zdolności psychiczne są tak imponujące, że musimy wziąć pod uwagę, iż formy (mode) świadomości są obecne w całym wszechświecie... Każdy byt posiada swoją własną spontaniczność wyłaniającą się z jego wnętrza i wyraża swą wewnętrzną wartość w taki sposób, że musimy stwierdzić, iż wszechświat jest wspólnotą podmiotów, a nie zbiorem przedmiotów”15. Rzeczywistość Chrystusa jest „wspólnotą” pomiędzy różnymi poziomami rzeczywistości: kosmicznym, społecznym i osobowym. Są

15 T. BerRy, The Great Work: Our Way Into the Future, New York: Bell Tower 1999, s. 81-82. 
w tradycji Kościoła takie koncepcje, które są mniej zorientowane na odkupienie, a bardziej na stworzenie - harmonijną relację pomiędzy człowiekiem i światem. Berry do takich koncepcji zalicza, m.in. duchowość okresu celtyckiego podkreślającą wartość życia (Celtic animate model); opiekuńczy model benedyktyńskich klasztorów (Benedictine custodial model); braterski model relacji człowieka i przyrody zaproponowany przez św. Franciszka z Asyżu (St. Francis fraternal model); model wypracowany przez Hildegardę z Bingen, w którym przyroda jest pojmowana w świętej relacji względem tego, co boskie, która to relacja jest źródłem płodności przyrody; integralny model Teilharda de Chardin, w myśl którego przyroda nie ogranicza się jedynie do procesów fizycznych, ale już u swych początków jest wyposażona w świadome, psychiczne i duchowe elementy. We wszystkich tych koncepcjach wizja Boga i boskiego świata jest głęboko obecna $\mathrm{w}$ sercu materii i jest $\mathrm{z}$ nią nierozerwalnie złączona ${ }^{16}$.

\section{Istnieje konieczność poprawienia sposobu ludzkiej obecności na planecie.}

Jest to wielkie zadanie naszych czasów. Podstawowym celem wszystkich dążeń człowieka powinno być uchronienie Ziemi przed popadnięciem w jakiś niedobór ze względu na sposób naszej obecności w świecie. Głównym celem medycyny powinno być zapewnienie zdrowia Ziemi. Berry pyta: jaki sens ma troska o to, by człowiek był zdrowy, jeśli przyjdzie mu żyć na śmiertelnie chorej planecie? Nasza ekonomia musi przestać koncentrować się na zysku, a zaangażować się w troskę o zdrowie planety.

W książce The Universe Story Berry kładzie podstawę pod najważniejszą, w jego opinii, kwestię - wypracowanie nowego opowiadania o stworzeniu, dzięki któremu możliwe będzie rozpoczęcie nowej ery samo-refleksji człowieka - ery, którą nazywa „erą ekologiczną” lub „erą ekozoiczną". Ta nowa era, w którą obecnie wkraczamy, uzupełnia i przezwycięża erę technologiczną. Era ekologiczna jest powrotem do zatraconego przez współczesnego człowieka podstawowego rozumienia wszechświata. Człowiek z pomocą nauki musi na nowo odkryć zasady rządzące ewolucją kosmosu począwszy od jego początku, poprzez ukształtowanie się Ziemi, powstanie na niej życia, aż po wyłonienie się świadomości. Berry uważa, że era ekologiczna musi uaktywnić te zasady, jeśli ludzkość ma mieć jakąś przyszłość. W jego opinii istnieją trzy takie zasady, które kierują funkcjonowaniem wszechświata: zróżnicowanie (differentiation), subiektywność (subiectivity) i wspólnota (communion) $)^{17}$.

16 Więcej na temat tych wyjątkowych sposobów kształtowania relacji człowieka względem przyrody obecnych w tradycji chrześcijańskiej mówi Berry w wywiadzie, jakiego udzielił Betty Didcoct. Por. Choosing Our Roots. Traditional Christian attitudes offer both problems and Promise for healing the earth, "In Context. A Quarterly of Humane Sustainable Culture" 1984, No 8, winter, s. 28-29.

17 Por. T. Berry, The Ecological Age, [w:] T. Berry, The Dream of the Earth, San Franciso: Sierra Club Books 1988, s. 44-45; por. także W. BarTLETT, Living by Surprise. A Christian Response to the Ecological Crisis, New York - Mahwah: Paulist Press 2003, s. 24-25. 
Zróżnicowanie jest obecne w całym wszechświecie, który ewoluuje, przybierając najbardziej różnorodne formy. Dobrą ilustracją tej wielości form, a zatem ich zróżnicowania, jest Ziemia oraz istniejące na niej niezliczone formy życia. Subiektywność, według Berry’ego, jest obecna we wszystkich elementach wszechświata i - wraz ze wzrostem złożoności form - przyjmuje coraz dojrzalsze postacie. W najprostszych formach jest swego rodzaju zdolnością do „wewnętrzności” (interiority), a wraz ze złożonością organicznych form przyjmuje postać subiektywności w systemie nerwowym, prowadząc do wykształcenia mózgu. Trzecia zasada to wspólnota wszystkich bytów obecnych we wszechświecie. Jedność całego zespołu systemów galaktycznych jest jednym z najbardziej podstawowych doświadczeń współczesnej fizyki. Jedność tę rozumieli już ludzie pierwotni, dziś nauka ponownie przybliża nam tę prawdę ${ }^{18}$.

Pogląd o konieczności przełamywania ery technologicznej i wkraczania w erę ekologiczną Thomas Berry wyraził bardzo dobitnie: „Historyczną misją naszych czasów jest ponowne odkrycie człowieka"19. Berry widzi naglącą potrzebę odnalezienia miejsca człowieka (jako gatunku) w świecie, w ramach całej wspólnoty istot żywych, przy uwzględnieniu ewolucyjnego kontekstu rozwoju wszechświata. Uważa on, że to nowe rozumienie człowieka i jego miejsca wśród innych bytów ożywionych i nieożywionych jest fundamentem ery ekologicznej. Berry wskazuje trzy sposoby przemiany człowieka, która będzie sprzyjała wkraczaniu ludzkości w erę ekologiczną: krytyczna refleksja, podzielanie marzeń oraz opowiadanie.

Dzięki krytycznej refleksji możemy zweryfikować nasze przekonania o człowieku i wszechświecie: zaczerpnięte $z$ historii; wiedzę dostarczaną nam przez współczesną naukę oraz prognozy przyszłości. Pomoże nam to podjąć decyzje na temat sposobu naszej teraźniejszej i przyszłej obecności w świecie ${ }^{20}$. Istotnym elementem krytycznej refleksji jest przejrzystość używanego w niej języka. „Jednym z najważniejszych zadań, przed jakim stają ekolodzy, jest stworzenie języka, w którym będzie można rzetelnie informować społeczeństwo na temat świata, wartości i postępu"21. Drugim elementem prowadzącym do przemiany człowieka jest podzielanie marzeń. Berry jest przekonany, że to ambitne marzenia skłaniają człowieka do podejmowania działań. Dziś potrzebujemy odważnych marzeń i śmiałych celów, które zainspirują jednostki i społeczeństwa do podejmowania odważnych i odpowiedzialnych decyzji prowadzących do koniecznych zmian i wprowadzających nas w erę ekologiczną. Trzecim, wskazanym przez Berry'ego, sposobem przemiany człowieka jest opowiadanie. Przez „opowiadanie” rozumie

\footnotetext{
18 Por. T. Berry, The Ecological Age, s. 44-46.

19 T. BERRY, The Great Work: Our Way Into the Future, s. 159.

20 Por. H. F. Greene, The Human Was Not Meant To Fail.

21 T. Berry, The Great Work: Our Way Into the Future, s. 63.
} 
on relację nowożytnej nauki na temat ewolucji wszechświata, pogłębioną przez filozoficzną refleksję nad osiągnięciami nauk szczegółowych ${ }^{22}$.

Ze względu na zagubienie współczesnego człowieka w świecie Berry proponuje stworzenie nowego „opowiadania”, które pozwoli człowiekowi na nowo zrozumieć otaczający go świat i ponownie odkryć swoje w nim miejsce i zadania $^{23}$. Thomas Berry jest zdania, że to zagubienie współczesnego czlowieka dotyczy zarówno członków wspólnot religijnych, jak osób, które nie identyfikują się $\mathrm{z}$ żadną religią. Proponuje więc stworzenie nowego opowiadania wyjaśniającego, jak byty zostały powołane do istnienia, na jakim etapie znajduje się dziś ludzkość i jak nadać sens i kierunek przyszłości człowieka. Tracąc sens, zatraciliśmy bowiem nasze wartości i podstawy naszego działania. Nowe opowiadanie o stworzeniu ma nam to przywrócić. W opinii Berry’ego ważnym etapem w historii ludzi Zachodu był wiek XIV i XV. Dżuma, która nawiedziła Europę w XIV w., spowodowała ogromne spustoszenie i skłoniła teologów do podkreślenia ważności tajemnicy odkupienia, zaburzając równowagę między doktryną odkupienia i stworzenia. Wiek XV był przełomem, po którym można mówić o zaistnieniu wspólnoty naukowej. Powstał w ten sposób rozdział pomiędzy wspólnotą szukającą w religii ratunku przed niebezpiecznym światem i wspólnotą ludzi nauki, którzy chcieli nad tym światem zapanować dzięki wiedzy. Podział ten trwał i pogłębiał się przez całe wieki. Dopiero współcześnie zauważa się pewne przejawy nowego dialogu między nauką i religią, który stwarza nadzieję na przełamanie tej historycznej zaszłości ${ }^{24}$.

Konsekwencją tego rozdziału jest zerwanie więzi łączącej człowieka $z$ wszechświatem, który Berry nazwał „autyzmem”. „Mówimy tylko do siebie. Nie rozmawiamy $z$ rzekami, nie słuchamy wiatru i gwiazd. Zerwaliśmy tę wielką konwersację. Przez jej zerwanie zakłóciliśmy wszechświat. Wszystkie obecne katastrofy są konsekwencją tego duchowego autyzmu [podkreślenie - RS]. (...) Na najgłębszym poziomie nie czujemy już braterstwa $z$ innymi formami życia na naszej planecie. Zatraciliśmy pierwotny sens przynależności do świata ożywionego. Naszym wyzwaniem jest zaspokojenie naszych podstawowych potrzeb bez niszczenia bioróżnorodności, która czyni naszą planetę tak życiodajną i bogatą"25.

W książce The Great Work Berry wskazuje na konieczność zmian, które muszą się dokonać, by ludzkość wkroczyła wreszcie w erę ekozoiczną. W jego opinii, zmiany muszą objąć: rządy, religie, korporacje i uniwersytety. Kluczową rolę mają

\footnotetext{
22 Zagadnienie „opowiadania” Berry porusza szeroko w książce The Universe Story: From the Primordial Flaring Forth to the Ecozoic Era, San Francisco: Harper 1992.

23 Por. T. Berry, Reinventing the Human at the Species Level, [w:] T. Berry, The Christian Future and the Fate of Earth, Naryknoll: Orbis Books 2009, s. 117-123.

24 Por. T. Berry, The New Story, [w:] T. BerRy, The Dream of the Earth, s. 125n.; por. także T. BERRY, The Great Work: Our Way Into the Future, s. 77-78.

2s Cyt. za R. HefFern, Thomas Berry.
} 
w tym procesie do odegrania uczelnie. Ich zadaniem jest nauczanie Opowiadania o wszechświecie (Universe Story) i uczynienie z ekologii centralnego przedmiotu programów nauczania na uniwersytetach. Ludzie potrzebują wiedzy na temat ich genetycznego związku $z$ innymi formami życia oraz wiedzy, że nasza przyszłość zależy od dobrostanu Ziemi ${ }^{26}$. Thomas Berry wskazuje nawet sześć konkretnych przedmiotów, które powinni zaliczyć wszyscy studenci ${ }^{27}$ :

Przedmiot 1: prezentacja sekwencji faz ewolucji wszechświata: formowanie się systemów galaktycznych i pierwiastków, z których powstaną kolejne elementy w następnych fazach; powstanie Ziemi w Układzie Słonecznym; powstanie życia na Ziemi w jego różnorodnych formach; wyłonienie się świadomości i rozwój ludzkiej kultury.

Przedmiot 2: prezentacja poszczególnych etapów rozwoju ludzkiej kultury: faza paleolityczna; neolityczna faza $\mathrm{z}$ tworzeniem się stałego osadnictwa; okres wielkich kultur religijnych; okres naukowo-technologiczny; wyłaniająca się era ekologiczna.

Przedmiot 3: prezentacja wielkich klasycznych cywilizacji, które zdominowały rozwój ludzkości na przestrzeni ostatnich kilku tysiącleci i legły u podstaw rozwoju języka, religii, duchowości, sztuki, nauki i literatury, a także struktur społecznych i politycznych, norm prawnych i systemów etycznych oraz rzemiosła i rekreacji.

Przedmiot 4: przedstawienie rozwoju ludzkości w okresie naukowo-technologicznym $z$ jego kulminacją w przebudzeniu ludzkiej świadomości względem następstwa czasu w kontekście historii wszechświata, Ziemi, życia i wspólnoty ludzkiej.

Przedmiot 5: przedstawienie kwestii związanych $\mathrm{z}$ wchodzeniem $\mathrm{w}$ erę ekologiczną: zacieśniająca się wzajemna łączność między ożywionymi i nieożywionymi systemami obecnymi na naszej planecie i we wszechświecie. Materiał powinien koncentrować się wokół ponownego umiejscowienia człowieka w szerokim kontekście wszechświata.

Przedmiot 6: przedstawienie systemu wartości oraz jego podstaw.

Oprócz edukacji, ważnym elementem wprowadzającym ludzkość w erę ekozoiczną jest dla Thomasa Berry'ego wypracowanie nowej koncepcji „praw przyrody". Berry utrzymuje, że najwięcej szkody środowisku naturalnemu wyrządziła Amerykańska Konstytucja, która legła u podstaw promocji praw człowieka, kompletnie pomijając prawa innych istot. Ważny wkład Thomasa Berry'ego w zmianę

26 Por. A. J. Angyal, Thomas Berry's Spirituality and the "Great Work", "The Ecozoic Reader" 3(2003)3, s. 39-40.

27 Por. T. Berry, The American College in the Ecological Age, [w:] T. BerRY, The Dream of the Earth, s. 99-108. 
dotychczasowego stosunku do środowiska przyrodniczego dokonał się na płaszczyźnie prawa dotyczącego ochrony środowiska. Zaproponował on wypracowanie nowego środowiskowego prawoznawstwa (Earth Jurisprudence). Zdając sobie sprawę $\mathrm{z}$ trudności związanych $\mathrm{z}$ wypracowaniem fundamentów praw istot pozaludzkich, Berry nawiązał do ekologii głębokiej oraz tomistycznej koncepcji prawa naturalnego. Jego zdaniem, prawo do istnienia istot pozaludzkich jest im przyrodzone i zakorzenione w samym wszechświecie, a nie w jakimś akcie prawnym stanowionym przez człowieka ${ }^{28}$. Berry wskazuje na dziesięć podstawowych zasad leżących u podstaw nowego ekologicznego prawoznawstwa ${ }^{29}$ :

1. Prawa pojawiają się tam, gdzie pojawia się istnienie. To, co determinuje istnienie, determinuje prawa.

2. Ponieważ w porządku fenomenologicznym wszechświat nie ma już dalszego kontekstu istnienia, jest skierowany na siebie (self-referent) $\mathrm{w}$ swym istnieniu i sam wyznacza zasady (self-normative) w swym działaniu. Wszechświat jest także podstawowym odniesieniem $w$ istnieniu i działaniu wszystkich bytów, które się z niego wyłoniły.

3. Wszechświat składa się $\mathrm{z}$ podmiotów, $\mathrm{z}$ którymi powinno się obcować, a nie przedmiotów, których można używać. Jako podmiot, każdy element wszechświata jest zdolny do posiadania praw.

4. Ziemski świat natury czerpie swoje prawa $z$ tego samego źródła, $z$ którego czerpie je człowiek: $\mathrm{z}$ wszechświata, który dał mu istnienie.

5. Każdy element wspólnoty ziemskiej, zarówno ożywiony, jak i nieożywiony, posiada trzy prawa: prawo do istnienia; prawo do habitatu lub miejsca egzystencji; prawo do wypełnienia swojej roli w wiecznie odnawiającym się procesie ziemskiej wspólnoty.

6. Wszystkie prawa istot nieożywionych są specyficzne dla funkcji (role-specific); prawa istot ożywionych są specyficzne dla poszczególnych gatunków (species-specific) i są ograniczone. Ludzie posiadają prawa człowieka. Różnica w prawach jest jakościowa, nie ilościowa. Prawa owada nie miałyby wartości dla drzewa lub ryby.

7. Prawa człowieka nie znoszą praw innych bytów do istnienia w ich naturalnym stanie. Ludzkie prawo własności nie jest absolutne. Prawo własności jest jedynie szczególną relacją pomiędzy danym ludzkim „właścicielem” i określonym kawałkiem „własności”, tak więc, obie strony powinny wypełniać swoje role w wielkiej wspólnocie tego, co istnieje.

8. Ze względu na to, że gatunki istnieją tylko $w$ formie jednostek, prawa odnoszą się do jednostek, a nie jedynie w sposób ogólny do gatunku.

28 Por. A. J. ANGYAL, Thomas Berry's Spirituality and the "Great Work", s. 40-41.

29 Por. T. Berry, Ten Principles for Jurisprudence Revision, [w:] T. Berry, M. E. Tucker (red.), Evening Thoughts. Reflecting on Earth as Sacred Community, s. 149-150. 
9. Przedstawione tu prawa są ufundowane na wewnętrznych relacjach, w które poszczególne elementy Ziemi wchodzą ze sobą. Ziemia jest pojedynczą wspólnotą związaną wzajemnie zależnymi relacjami. Żaden organizm nie jest w stanie wyżywić się sam. Każdy element ziemskiej wspólnoty jest bezpośrednio lub pośrednio zależny od każdego innego członka tej wspólnoty w kontekście pożywienia i troski niezbędnej dla swego przetrwania. Wzajemne dostarczanie sobie pokarmu, łącznie $\mathrm{z}$ relacją drapieżnik-ofiara, jest zgodne $\mathrm{z}$ rolą, którą każdy element Ziemi posiada w ramach rozległej wspólnoty istnienia.

10. Dla osobistego spełnienia ludzie mają nie tylko potrzebę, ale i prawo dostępu do świata przyrody w celu zaspokojenia swych potrzeb fizycznych, potrzeby zadziwienia niezbędnego ludzkiej inteligencji, potrzeby piękna nieodzownego ludzkiej wyobraźni i potrzeby intymności pożądanej dla ludzkich emocji.

\section{Zakończenie}

Myśl Thomasa Berry'ego spotkała się z życzliwym przyjęciem i zainicjowała wiele teoretycznych i praktycznych projektów. Pojawiły się jednak także głosy krytyki. Niektórzy uważają, że zbyt daleko posunął się on w usprawiedliwianiu eksploatacyjnej postawy człowieka względem przyrody, uzasadniając to argumentacją biblijną. Inni krytycznie oceniali jego projekt wprowadzenia „ekologicznych przedmiotów" do curriculum studiów uniwersyteckich lub twierdzili, że kryzys ekologiczny jest znacznie bardziej złożony i zaproponowana przez Berry'ego kuracja jest niewystarczająca. Jednak nawet jego adwersarze podziwiali jego realizm, głębię myśli, twórczą wyobraźnię i odwagę intelektualną ${ }^{30}$. Czy zaproponowany przez Thomasa Berry’go sposób przezwyciężenia kryzysu ekologicznego okaże się skuteczny? Trudno to dziś osądzić.

Aktualny stan środowiska naturalnego i zachowawcza postawa rządów najbogatszych państw świata skłania do smutnej refleksji - nikt za nas tego nie zrobi. Sami musimy zakasać rękawy i zabrać się do pracy na rzecz ocalenia Ziemi. Thomas Berry w książce pod tytułem Great Work (Wielkie Dzieło) ujął to następująco: „Stajemy wobec wielkiego dzieła. Wszyscy mamy swoje zajęcia - niektórzy z nas są nauczycielami, inni uzdrowicielami, inni uprawiają ziemię, a jeszcze inni parają się innymi zajęciami. Mamy wiele różnych obowiązków. Ale oprócz określonych prac, które wykonujemy i osobistego życia, które wiedziemy, mamy wielkie dzieło, w które każdy jest włączony, a z którego nikt nie może być wykluczony. Tym dziełem jest przejście od śmiertelnej ery kenozoicznej do wyłaniającej się z historii planety Ziemi ery ekozoicznej i to jest to Wielkie Dzieło" ${ }^{31}$.

\footnotetext{
30 Por. M. Hope, J. Young, Thomas Berry and a New Creation Story, s. 752-753.

31 T. BERRY, The Great Work: Our Way Into the Future, s. 5.
} 
Thomas Berry, jako jeden z pierwszych, uświadomił sobie, że technologia może jedynie wspomagać przeciwdziałanie kryzysowi ekologicznemu, ale nie jest w stanie go zażegnać. Źródła tego kryzysu leżą bowiem znacznie głębiej $\mathrm{w}$ samym człowieku i w tym właśnie kierunku powinny być skierowane nasze zabiegi, jeśli życie na Ziemi w obecnej formie ma przetrwać. Berry miał świadomość upływającego czasu i zbliżającego się punktu, spoza którego nie będzie już odwrotu. Dlatego, z wielkim zapałem i w charyzmatyczny sposób, skupiał ludzi i zarażał ich pasją do swoich pomysłów. Szczególnie zależało mu na takiej edukacji człowieka, która zmieni go do tego stopnia, że będzie on zdolny do zapoczątkowania ery ekozoicznej ${ }^{32}$.

Ukuty przez niego termin „ekozoiczny” to zbitka dwóch greckich słów: oíkos - dom i zoè- życie. Ekozoiczny znaczy zatem tyle, co "dający schronienie życiu” lub dosłownie „będący domem życia”. Wydaje się, że różnorodne zainteresowania Thomasa Berry’ego oraz liczne jego inicjatywy nabierają spójnego wyrazu w momencie, gdy spojrzymy na nie $\mathrm{z}$ takiego właśnie punktu widzenia - ukochania i ochrony życia. Ten wyjątkowy uczony był przekonany, że człowieka można zmienić, można go wychować do troski o życie, a nadejście ery ekozoicznej jest tylko kwestią czasu. Chociaż „wielkie dzieło" wciąż jeszcze przed nami, a jego rezultaty nadal pozostają niepewne, to jednak już dziś możemy powiedzieć, że era ekozoiczna ma swojego proroka i jest nim Thomas Berry. Prorok ten nie tylko zapowiedział nadchodzące zmiany, ale pozostawił po sobie liczne grono uczniów i naśladowców, którzy kontynuują jego „wielkie dzieło".

32 Por. T. BERry, The Christian Future and the Fate of Earth, s. 69-71. 